\title{
Knowledge, Nutritional Value and Uses of Some Non-Conventional Plant Foods
}

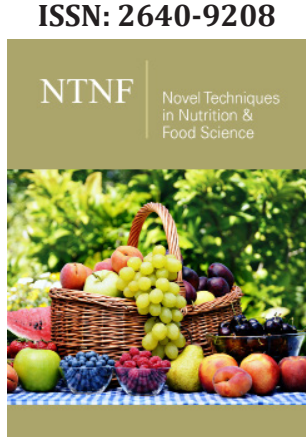

*Corresponding author: Socorro Vanesca Frota Gaban, Universidade Federal do Ceará, Department of Food Engineering, Campus do Pici, Brazil

Submission: 画 November 05, 2020

Published: 眥 December 16, 2020

Volume 5 - Issue 3

How to cite this article: Socorro Vanesca Frota Gaban, Otília Mônica Alves Borges. Knowledge, Nutritional Value and Uses of Some NonConventional Plant Foods. Nov Tech Nutri Food Sci. 5(3). NTNF. 000613. 2020. DOI: 10.31031/NTNF.2020.05.000613

Copyright@ Socorro Vanesca Frota Gaban. This article is distributed under the terms of the Creative Commons Attribution 4.0 International License, which permits unrestricted use and redistribution provided that the original author and source are credited.

\author{
Socorro Vanesca Frota Gaban ${ }^{1 *}$ and Otília Mônica Alves Borges ${ }^{1,2}$ \\ ${ }^{1}$ Universidade Federal do Ceará, Department of Food Engineering, Campus do Pici, Brazil \\ ${ }^{2}$ Federal Institute of Education, Science and Technology ofCeará, Campus Aracati, Brazil
}

\begin{abstract}
With the increased focus on a healthy diet based on the consumption of organic and natural foods, nonconventional food plants are becoming a more prevalent option to add variety and greater nutritional value to the daily diet. Non-conventional foods are a reliable and inexpensive alternative healthy food source to replace or complement current conventional food choices. These underutilized plants have the potential to be used not only in daily food preparation as an ingredient in soups, salads, etc., but also as a source of dietary supplements, for new food formulations and product development. These plants are also endowed with bioactive compounds and antioxidant activity, among others. This literature review provides an overview about some of the most popular plants, their uses, nutritional aspects, and medicinal properties.
\end{abstract}

Keywords: Organic; Plants; Healthy; Nutrition

\section{Introduction}

Countries in the world rich in floral biodiversity and abundant vegetation, benefit from a variety of non-conventional edible plants. These plants are vegetables and fruits unusual in daily life. They are defined as wild and semi-wild species that naturally grow in forests, forest margins, community lands, degraded and discarded lands [1]. The consumption of these plants stimulates food diversification, maintenance of the forest, enhancement of natural resources and reduction of environmental impacts if carried out in a sustainable manner [2]. Since they are drought-resistant plants that are simple to cultivate, grow organically and do not need soil additives, maintenance or care in planting, without the need to use pesticides or chemicals, as they occur with those that are frequently consumed. However, many of these plants, although available at low cost, are still unknown and underutilized by a significant portion of the population [2].

These plants are known to be part of the culture, identity, agricultural practices, and eating habits of various traditional populations in different regions of the World. The increasing influence, and invasion of urban culture in rural areas and tribal societies has contributed to the rapid erosion of ethnic culture and knowledge of non-conventional food plants. Additionally, increased accessibility to modern, genetically modified vegetables, has led to disuse of these plants in the modern diet. Thus, the lack of supply of unconventional plants made them unknown to new generations, as they started to have reduced economic and social expression, losing space for other products [2,3].

Nom-conventional food plants are of great importance for human consumption because they can provide vitamins, dietary fiber, carbohydrates, minerals, and proteins. In addition, they have sensory characteristics that facilitate their consumption, being the same consumed "in natura" or used in raw salads, soups, cookies, pasta, puree, and omelettes. Thus, the consumption of these unconventional vegetables can present itself as an excellent nutritional option, especially for populations with less purchasing power. In some countries of the world, 
there are still established practices of using unconventional food plants as a food source in times of famine and natural disasters [47].

The use of non-conventional food plants has been increasing by people looking for a healthier life, due its high nutrition value. In addition, they are usually seasonal and regional reducing consumer impact on the environment and contributing to a more sustainable food system. They are easy and cheap plants to find and can be a low-cost vegetable alternative. Moreover, they are an option to escape the food monotony that the food industry imposes, for the perpetuation of good eating habits [8]. In addition, the intake of these non-conventional vegetables is known for their pharmacological properties. The following are nutritional summaries of some of the most popular non-conventional plants available (Pereskia aculeate, Sonchus oleraceus, Basella alba, Hibiscus sabdariffa, Xanthosoma sagittifolium, Stachys byzantine).

\section{Pereskia aculeata}

The genus Pereskia (Cactaceae family), popularly known as orapro-nobis, is a leafy climbing cactus, originally from the American continent. Leaves contain high levels of protein when compared to other plants commonly used for human food, and it is a remarkable source of nutritionally important minerals and vitamins (vitamin C, folic acid, calcium, iron and zinc). It also presents in its composition Sitosterol, stigmasterol, flavonoids, and phenols. Widely consumed in soups, sausages, scrambled eggs, omelettes and salads $[9,10]$. Studies also show that consumption of Pereskia can result in the improvement of biological parameter markers of diseases such as protein malnutrition, iron deficiency anemia, dyslipidemia, obesity, diabetes mellitus [11]. The leaves have antioxidant activity and in vitro antimicrobial and antifungal activities $[10,12]$.

\section{Sonchus oleraceus}

Sonchus oleraceus $L$, a member of the Asteraceae family, originates from Europe and is found almost everywhere in the world. It is popularly known as milkweed, wild chicory, smooth milkweed, jealousy or sawmill. It contains appreciable amounts of mineral elements (iron, zinc, manganese, copper, calcium), vitamin $\mathrm{C}$ and bioactive compounds such polyphenols [13]. It is an important herb used in popular medicine to treat liver disease, inflammation and infections. It is used as ingredient in some preparation and salads. It has various pharmacological activities including antioxidant, antibacterial, antidiabetic, and antimicrobial [14].

\section{Basella alba}

Basella alba L. belongs to the family Basellaceae [15]. Originating in India, it is a fast-growing perennial vine and extremely heat tolerant. It is also known as the Malabar spinach, Ceylon spinach, Indian spinach, vine spinach, Chinese spinach. The leaves are very low in calories and contain high amounts of vitamins and minerals such as calcium, iron, vitamins $\mathrm{A}$ and $\mathrm{C}$, potassium, folate, and antioxidants $[15,16]$. The leaves can be sautéed and used in the preparation of pies, soups and salads. The fruit is extremely dark when ripe and, when crushed, produces a very dark red juice. It has various pharmacological activities including hypoglycemic, antioxidant, gastroprotective and hypocholesterolemic [17].

\section{Hibiscus sabdariffa}

Hibiscus sabdariffa, also known as roselle, is widely cultivated in both tropical and subtropical regions. Its flowers are used in the preparation of hot and cold drinks, fermented drinks, wine, jelly, and ice cream. The seeds are eaten roasted or ground into soups and sauces, while the leaves and sprouts are eaten raw or cooked, as a vegetable or condiment with a sour taste. Hibiscus sabdariffa has also been used as a folk remedy and is well known for its antibacterial, antidiabetic, antihypertensive, antioxidant and diuretic properties. Its pharmacological effect is attributed to its bioactive constituents, such as anthocyanins and flavonoids $[18,19]$.

\section{Xanthosoma sagittifolium}

Xanthosoma sagittifolium (Araceae family), popularly known as Cocoyam, originates from tropical America, most probably Central and South America. It is among the six most important root and tuber cultures in the world, because of its high nutritional value, provides sustenance for over 400 million people [20]. It is considered an appreciable source of energy, protein, vitamins and minerals, such as zinc, potassium, calcium, phosphorus, magnesium and nicotinic acid. You can eat the rhizome, petiole and the leaf. The leaf contains vitamins $A$ and $C$, in addition to minerals [21,22].

\section{Stachys byzantine}

Stachys byzantina $K$. Koch. belongs to the family Lamiaceae. It is an Iranian endemic species, which could be found in many parts of Armenia, Turkey and Iraq. The plant is known as 'lamb's ear' or 'lamb's tongue. Stachys species are widely consumed in different countries as aromatic herbal teas. These have been used in traditional medicine as an antioxidant, antibacterial, anti-ulcer, anti-anxiety, anti-inflammatory and anti-nephritic. The leaves contain appreciable amounts of mineral elements, such as zinc, potassium, calcium, phosphorus and magnesium [23].

\section{Conclusion}

Increasing the consumption of non-conventional plants can improve the nutritional status of economically disadvantaged people, stimulate an alternative source of income in family farming, favor nutritional diversification, and enable greater care for the environment by omitting the need for pesticides. Although some scientific studies have been done to examine their health and nutritional benefits, more studies need to be completed to fully understand these food sources and further educate the public on possible uses. Research and the implementation of public policies that promote the use, rebirth, and enhancement of native species can contribute to nature conservation and sustainable development and increase the number of food sources. 


\section{References}

1. Chandra KS, Gogoi D, Gautam KH, Handique AK (2016) Nutritive values of some non-conventional leafy vegetables and scarcity food plants of north east India. Afr J Food Sci 10(11): 340-343.

2. Luizza MW, Young H, Kuroiwa C, Evangelista P, Worede A, et al. (2013) Local knowledge of plants and their uses among women in the bale mountains, Ethiopia. Ethnobot Res Appl 11: 315-339.

3. Voggesser G, Lynn K, Daigle J, Lake F K, Ranco D (2013) Cultural impacts to tribes from climate change influences on forests. Clim Change 120(3): 615-626.

4. Silva LFL, Souza DC, Resende LV, Nassur RCMR, Samartini CQ, et al (2018) Nutritional evaluation of non-conventional vegetables in Brazil. An Acad Bras Ciênc 90(2): 1775-1787.

5. Ejoh RA, Nkonga DV, Inocent G, Moses MC (2007) Nutritional components of some non-conventional leafy vegetables consumed in Cameroon. Pak J Nutr 6(6): 712-717.

6. Rocha DRC, Júnior GAP, Vieira G, Pantoja L, Santos AS, et al. (2008) Noodles added of ora-pro-nobis (Pereskia aculeata Miller) dehydrated. Alim Nutr 19(4): 459-465.

7. Lara MCB, Maynard DC, Vilela JS, Silva MC, Lima CMAM (2019) Preparation, acceptability and evaluation of the nutritional composition of a taioba cookie recipe, a PANC. Braz J Dev 5(11): 24099-24109.

8. Oliveira HAB, Anunciação PC, Silva BP, Souza AMN, Pinheiro SS, et al (2019) Nutritional value of non-conventional vegetables prepared by family farmers in rural communities. Cien Rural 49(8): e20180918.

9. Almeida MEF, Junqueira AMB, Simão AA, Corrêa AD (2014) Chemical characterization of the non-conventional vegetable known as ora-pronobis. Biosci J 30(1): 431-439.

10. Kumar SS, Prabhakaran M, Giridhar P (2015) Nutrition facts and functional attributes of foliage of Basella spp. LWT- Food Sci Technol 64(1): 468-474.

11. Souza LF, Caputo L, Barros IBI, Fratianni F, Nazzaro F, et al. (2016) Pereskia aculeata Muller (Cactaceae) leaves: chemical composition and biological activities. Int J Mol Sci 17(9): 1478.
12. Takeiti CY, Antonio GC, Motta EM, Queiroz FPC, Park KJ (2009) Nutritive evaluation of a non-conventional leafy vegetable (Pereskia aculeata Miller). Int J Food Sci Nutr 60(1): 148-160.

13. Jimoh FO, Adedapo AA, Afolayan AJ (2011) Comparison of the nutritive value, antioxidant and antibacterial activities of Sonchus asper and Sonchus oleraceus. Rec Nat Prod 5(1): 29-42.

14. Puri AV, Khandagale PD, Ansari YN (2018) A review on ethnomedicinal, pharmacological and phytochemical aspects of Sonchus oleraceus linn. (asteraceae) Int J Pharma Bio Sci 8(3): 01-09.

15. Singh M, Kumari R, Kotecha M (2016) Basella rubra linn-A review. Int J Ayu Pharm Chem 5(1): 206-223.

16. Singh M, Kumari R, Nandini D, Kotecha M (2016) Preliminary phytochemical screening of Basella rubra Linn. J Pharmacogn Phytochem 5(4): 224-226.

17. Kumar SS, Manoj P, Giridhar P, Shrivastava R, Bharadwaj M (2015) Fruit extracts of Basella rubra that are rich in bioactives and betalains exhibit antioxidant activity and cytotoxicity against human cervical carcinoma cells. J Funct Foods 15: 509-515.

18. Rocha ICD, Bonnlaender B, Sievers H, Pischel I, Heinrich M (2014) Hibiscus sabdariffa L.-a phytochemical and pharmacological review. Food Chem 165: 424-443.

19. Snafi AE (2018) Pharmacological and therapeutic importance of Hibiscus sabdariffa-A review. Int J Pharm Res 10(3): 451-475.

20. Boakye AA, Manu FDW, Oduro I, Ellis WO, Gudjónsdóttir M, et al. (2018) Utilizing cocoyam (Xanthosoma sagittifolium) for food and nutrition security: A review. Food Sci Nutr 6(4): 1-11.

21. Ndabikunze BK, Talwana HAL, Mongi RJ, Zacharia AI, Serem AK, et al. (2011) Proximate and mineral composition of cocoyam (Colocasia esculenta L. and Xanthosoma sagittifolium L.) grown along the Lake Victoria Basin in Tanzania and Uganda. Afr J Food Sci 5(4): 248-254.

22. Tovar DC, Jáuregui RN, Vega AB, Moreno ML (2019) Characterization of cocoyam (Xanthosoma spp.) corn flour from the Nazareno cultivar. Food Sci Technol 39(2): 349-357.

23. Gören AC (2014) Use of Stachys Species (Mountain Tea) as herbal tea and food. Rec Nat Prod 8(2): 71-82. 